\title{
PENANGGUHAN PENAHANAN TERHADAP TERSANGKA ATAU TERDAKWA DALAM PERKARA PIDANA NARKOBA
}

Oleh :

Iman Hidayat*

\begin{abstract}
ABSTRAK
Kitab Undang-Undang Hukum Acara Pidana memberikan saluran hukum bagi seseorang untuk ditangguhkan penahanannya dalam perkara Narkoba dengan menggunakan jaminan (uang atau orang) maupun tidak. Hal ini selaras dengan asas "presumption of innocent" yaitu asas praduga tak bersalah yang menganggap seseorang wajib dianggap tidak bersalah sebelum adanya putusan pengadilan yang menyatakan kesalahannya dan memperoleh kekuatan hukum tetap. Wewenang penangguhan penahanan dapat diberikan oleh semua instansi penegak hukum. undang-undang tidak menentukan alasan penangguhan dan memberi kebebasan dan kewenangan penuh kepada instansi yang menahan untuk menyetujui atau tidak menangguhkan, sepatutnya instansi yang bersangkutan mempertimbangkan dari sudut kepentingan dan ketertiban umum dengan jalan pendekatan sosiologis, psikologis dan preventif. Oleh karena itu, kebebasan dan kewenangan menangguhkan penahanan, jangan semata-mata bertitik tolak dari sudut persyaratan dan jaminan yang ditetapkan, tapi juga harus mengkaji dan mempertimbangkan lebih dalam dari sudut yang lebih luas
\end{abstract}

Kata Kunci: Penangguhan Penahanan, Tersangka/Terdakwa, Narkoba

\section{A. Latar Belakang}

Dewasa ini kejahatan narkoba semakin meningkat diiringi dengan perkembangan teknologi yang semakin canggih pula. Adanya teknologi yang canggih digunakan oleh pecandu narkoba untuk memesan narkotika kepada pengedar melalui telepon atau handphone dan kemudian narkoba tersebut diantarkan pada suatu tempat yang sudah ditentukan. Selain itu, apabila pengiriman narkoba dilakukan antar provinsi, maka pengirimannya menggunakan berbagai macam modus operandi termasuk melalui pengiriman jasa titipan kilat. Selain itu, penyebaran narkoba sekarang ini tidak hanya di kota-kota besar saja melainkan sudah merambat masuk ke pedesaan.

Dengan demikian, para pelaku narkoba untuk menyebarkan barang haram tersebut menggunakan modus operandi yang tinggi dalam penyebaran kejahatan narkoba itu. Tidak hanya itu saja, akibat dari penyebaran narkoba yang semakin meningkat telah banyak korban berjatuhan karena menyalahgunakan narkoba. Untuk

\footnotetext{
* Pengajar Program Magister Ilmu Hukum Unbari.
} 
itu, diperlukan suatu penegak hukum yang berperan dalam menanggulangi kejahatan narkoba, salah satunya adalah kepolisian.

Tugas Kepolisian Negara Republik Indonesia yang bersumber dari substansi tugas pokok memelihara keamanan dan keterlibatan masyarakat dan menggambarkan fungsi-fungsi teknis dalam rangka pelaksanaan kewajiban umum kepolisian. ${ }^{1}$

Undang-Undang Nomor 8 Tahun 1981 (KUHAP) memberikan peran utama kepada Kepolisian Negara Republik Indonesia untuk melaksanakan tugas penyelidikan dan penyidikan tindak pidana (secara umum) tanpa batas lingkungan kuasa, sepanjang masih termasuk dalam lingkup hukum publik, sehingga pada dasarnya Kepolisian Negara Republik Indonesia oleh KUHAP diberi kewenangan untuk melakukan penyelidikan dan penyidikan terhadap semua tindak pidana. ${ }^{2}$ Terkait dengan hal ini, maka Kepolisian Negara Republik Indonesia berwenang untuk melakukan penyelidikan dan penyidikan terhadap tindak pidana narkoba.

Dengan demikian, agar tindak pidana narkoba tidak merajalela, maka penangkapan harus dengan atas perintah penyidik dan yang dimaksud dengan penyidik termasuk di dalamnya adalah pejabat Kepolisian Negara Republik Indonesia atau pejabat Pegawai Negeri Sipil tertentu yang diberi wewenang khusus oleh undangundang untuk melakukan penyidikan. Perintah yang dimaksud berupa surat perintah yang dibuat secara tersendiri, dikeluarkan sebelum penangkapan dilakukan, hal ini tidak berlaku apabila dalam hal tertangkap tangan. ${ }^{3}$

Setelah melakukan penangkapan, Kepolisian Negara Republik Indonesia juga melakukan penahanan guna agar si pelaku tindak pidana narkoba tidak melarikan diri demi pemeriksaan perkara lebih lanjut. Dengan demikian, untuk melakukan penahanan terhadap tersangka atau terdakwa harus mengetahui dasar pertimbangan untuk diadakan penahanan.

\section{B. Perumusan Masalah}

Berdasarkan uraian pada latar belakang di atas, maka penulis akan membatasi permasalahan yang akan dibahas, sebagai berikut :

\footnotetext{
${ }^{1}$ Pudi Rahardi, Hukum Kepolisian Kemandirian, Profesionalisme dan Reformasi Polri, Cetakan Pertama, Laksbang Grafika, Surabaya, 2014, hal. 71.

${ }^{2}$ Ibid, hal. 73.

${ }^{3}$ Bambang Poernomo, Orientasi Hukum Acara Pidana Indonesia, Amarta Buku, Yogyakarta, 2000, hal. 67.
} 
1. Apakah pengertian penangguhan penahanan dan alasan apa saja yang sah untuk mengajukan penangguhan penahanan?

2. Bagaimana pelaksanaan penangguhan penahanan terhadap tersangka atau terdakwa dalam perkara pidana narkoba?

\section{Pengertian Penangguhan Penahanan dan Alasan Apa Saja Yang Sah Untuk Mengajukan Penangguhan Penahanan}

Tahanan artinya sesuatu yang menahan, menghambat atau simpanan, atau orang yang ditahan atau dipenjara, penahanan artinya perbuatan atau cara atau hal menahan, juga berarti penolakan, penghambatan atau penangkapan.

Menurut Kitab Undang-Undang Hukum Acara Pidana, penahanan adalah penempatan tersangka atau terdakwa di tempat tertentu oleh penyidik atau penuntut umum atau oleh hakim. Penahanan itu dapat dilakukan untuk kepentingan penyidikan oleh penyidik (polisi) atau penyidik pembantu (polisi), untuk kepentingan penuntut oleh penuntut umum (jaksa) dan untuk kepentingan pemeriksaan hakim di sidang pengadilan oleh hakim ketua.

Penahanan polisi berlaku selama 20 hari atau diperpanjang sampai 40 hari lagi, penahanan jaksa berlaku selama 20 hari atau boleh diperpanjang paling 30 hari lagi atas perkenan ketua pengadilan negeri. Kemudian penahanan oleh hakim paling lama 30 hari atau diperpanjang atas perkenan ketua pengadilan negeri sampai paling lama 60 hari. ${ }^{4}$

Menurut Pasal 1 butir 21 Kitab Undang-Undang Hukum Acara Pidana, penahanan adalah penempatan tersangka atau terdakwa di tempat tertentu oleh penyidik atau penuntut umum atau hakim dengan penempatannya, dalam hal serta menurut cara yang diatur dalam undang-undang ini.

Dasar pertimbangan untuk diadakan penahanan dijelaskan dalam Pasal 21 ayat (1) Kitab Undang-Undang Hukum Acara Pidana yaitu :

1. Tersangka atau terdakwa dikhawatirkan melarikan diri.

2. Tersangka atau terdakwa merusak atau menghilangkan barang bukti.

3. Tersangka atau terdakwa mengulangi tindak pidana.

Di samping alasan untuk dapat dilakukan penahanan, undang-undang juga memberikan saluran hukum bagi seseorang untuk ditangguhkan penahanannya dengan menggunakan jaminan (uang atau orang) maupun tidak. Hal ini selaras dengan asas

${ }^{4}$ Hilman Hadikusuma, Bahasa Hukum Indonesia, PT. Alumni, Bandung, 2010, hal. 166. 
"presumption of innocent" yaitu asas praduga tak bersalah yang menganggap seseorang wajib dianggap tidak bersalah sebelum adanya putusan pengadilan yang menyatakan kesalahannya dan memperoleh kekuatan hukum tetap.

Penangguhan penahanan menurut Pasal 31 ayat (1) Kitab Undang-Undang Hukum Acara Pidana adalah atas permintaan tersangka atau terdakwa, penyidik atau penuntut umum atau hakim, sesuai dengan kewenangan masing-masing, dapat mengadakan penangguhan penahanan dengan atau tanpa jaminan uang atau jaminan orang, berdasarkan syarat yang ditentukan.

Menurut M. Yahya Harahap, pengertian penangguhan penahanan yaitu mengeluarkan tersangka atau terdakwa dari penahanan sebelum batas waktu penahanan berakhir. Tahanan yang resmi dan sah masih ada dan belum habis, namun pelaksanaan penahanan masih harus dijalani tersangka atau terdakwa yang ditangguhkan, sekalipun masa penahanan yang diperintahkan kepadanya belum habis. ${ }^{5}$

Terjadinya penangguhan penahanan seolah-olah didasarkan pada "bentuk kontrak" atau "perjanjian" dalam hubungan perdata. Itu sebabnya cenderung untuk mengatakan terjadinya penangguhan penahanan berdasarkan "perjanjian" antara orang tahanan dengan pihak instansi yang menahan. Orang tahanan berjanji akan melaksanakan dan memenuhi syarat dan jaminan yang ditetapkan instansi yang menahan, dan sebagai "imbalan" pihak yang menahan mengeluarkan dari tahanan dengan menangguhkan penahanan. ${ }^{6}$

Wewenang penangguhan penahanan dapat diberikan oleh semua instansi penegak hukum. Pasal 31 ayat (1) tidak membatasi kewenangan penangguhan penahanan terhadap instansi tertentu saja. Masing-masing instansi penegak hukum yang berwenang memerintahkan penahanan, sama-sama mempunyai wewenang untuk menangguhkan penahanan. Baik penyidik, penuntut umum, maupun hakim mempunyai kewenangan untuk menangguhkan penahanan, selama tahanan yang bersangkutan masih berada dalam lingkungan tanggung jawab yuridis mereka.

Tentang alasan penangguhan penahanan tidak disinggung dalam Pasal 31 KUHAP maupun dalam penjelasan pasal tersebut. Ditinjau dari segi yuridis, mengenai alasan penangguhan dianggap tidak relevan untuk dipersoalkan. Persoalan pokok bagi

${ }^{5}$ Yahya Harahap, Pembahasan Permasalahan KUHP dan Penerapan KUHAP, Sinar Grafika, Jakarta, 2002, hal. 209.

${ }^{6} \mathrm{R}$. Soesilo, Tugas Kewajiban dan Kewenangan Penyidik, Jaksa, Hakim (Dalam Penyelesaian Perkara Pidana Menurut KUHAP), Sinar Grafika, Bandung, 2003, hal. 43. 
hukum dalam penangguhan berkisar pada masalah "syarat" dan "jaminan penangguhan".

Berdasarkan penjelasan Pasal 31 Kitab Undang-Undang Hukum Acara Pidana menyatakan bahwa penangguhan penahanan adalah faktor yang menjadi dasar dalam pemberian penangguhan penahanan. Penangguhan penahanan harus dimajukan oleh tersangka atau keluarganya ataupun dapat juga dimajukan oleh penasehat hukum tersangka dengan suatu jaminan uang atau jaminan orang. Berdasarkan syarat yang telah ditentukan.

Apabila suatu penangguhan penahanan tersebut dikabulkan oleh pejabat yang melakukan penahanan maka berdasarkan ketetapan dalam Kitab Undang-Undang Hukum Acara Pidana, pejabat tersebut dapat menetapkan suatu jaminan baik berupa jaminan uang ataupun jaminan orang, penetapan ada atau tidaknya suatu jaminan dalam KUHP bersifat fakultatif. ${ }^{7}$

Menurut M. Yahya Harahap berpendapat bahwa penetapan jaminan dalam penangguhan penahanan tidak mutlak, tanpa jaminan tindakan pemberian penangguhan penahanan tetap sah menurut hukum. Cuma agar syarat penangguhan penahanan benarbenar ditaati, ada baiknya penangguhan dibarengi dengan penetapan jaminan. Cara yang demikian yang lebih dapat dipertanggungjawabkan demi upaya memperkecil tahanan melarikan diri. ${ }^{8}$

Namun, sekalipun undang-undang tidak menetnukan alasan penangguhan dan memberi kebebasan dan kewenangan penuh kepada instansi yang menahan untuk menyetujui atau tidak menangguhkan, sepatutnya instansi yang bersangkutan mempertimbangkan dari sudut kepentingan dan ketertiban umum dengan jalan pendekatan sosiologis, psikologis dan preventif. Oleh karena itu, kebebasan dan kewenangan menangguhkan penahanan, jangan semata-mata bertitik tolak dari sudut persyaratan dan jaminan yang ditetapkan, tapi juga harus mengkaji dan mempertimbangkan lebih dalam dari sudut yang lebih luas. ${ }^{9}$

Mengenai syarat penangguhan penahanan ini, selanjutnya dapat dilihat pada penjelasan Pasal 31 ayat (1) KUHAP yaitu tersangka atau terdakwa :

1. Wajib lapor

${ }^{7}$ http://one.indoskripsi.com/node/10242, jaminan penangguhan penahanan dalam proses pidana, diakses tanggal 9 November 2018.

${ }^{8}$ Yahya Harahap, Op. Cit., hal. 164.

${ }^{9}$ Ibid, hal. 210-211. 
2. Tidak keluar rumah

3. Tidak keluar kota

D. Pelaksanaan Penangguhan Penahanan Terhadap Tersangka atau Terdakwa Dalam Perkara Pidana Narkoba

Dalam Peraturan Pemerintah Nomor 27 Tahun 1983 tentang Pelaksanaan KUHAP diatur bahwa dalam permintaan penangguhan penahanan, ada jaminan yang disyaratkan yang bisa berupa :

1. Jaminan Uang (Pasal 35)

- Jaminan uang ini ditetapkan oleh pejabat yang berwenang sesuai dengan tingkat pemeriksaan dan disimpan di Kepaniteraan Pengadilan Negeri.

- Penyetoran uang jaminan ini dilakukan sendiri oleh pemohon atau penasihat hukumnya atau keluarganya dan untuk itu Panitera memberikan tanda terima.

- Penyetoran ini dilakukan berdasar "formulir penyetoran" yang dikeluarkan instansi yang bersangkutan.

- Bukti setoran ini dibuat dalam rangkap tiga sesuai ketentuan angka 8 huruf f Lampiran Keputusan Menteri Kehakiman Nomor M.14-PW.07.03/1983. Tembusan tanda penyetoran tersebut oleh panitera disampaikan kepada pejabat yang berwenang sesuai dengan tingkat pemeriksaan untuk menjadi dasar bagi pejabat yang menahan mengeluarkan surat perintah atau surat penetapan penangguhan penahanan.

- Apabila kemudian tersangka atau terdakwa melarikan diri dan setelah melewati waktu 3 (tiga) bulan tidak diketemukan, uang jaminan tersebut menjadi milik negara dan disetor ke Kas Negara.

2. Jaminan Orang (Pasal 36)

- Orang penjamin bisa penasihat hukumnya, keluarganya, atau orang lain yang tidak mempunyai hubungan apapun dengan tahanan.

- Penjamin memberi "pernyataan" dan kepastian kepada instansi yang menahan bahwa dia "bersedia" dan bertanggung jawab memikul segala resiko dan akibat yang timbul apabila tahanan melarikan diri.

- Identitas orang yang menjamin harus disebutkan secara jelas. 
- Instansi yang menahan menetapkan besarnya jumlah uang yang harus ditanggung oleh penjamin, yang disebut "uang tanggungan" (apabila tersangka/terdakwa melarikan diri).

- Pengeluaran surat perintah penangguhan didasarkan atas surat jaminan dari si penjamin.

Timbulnya kewajiban orang yang menjamin menyetor uang tanggungan yang ditetapkan dalam perjanjian penangguhan penahanan :

a. Apabila tersangka/terdakwa melarikan diri.

b. Dan setelah lewat 3 bulan tidak ditemukan.

c. Penyetoran uang tanggungan ke kas negara dilakukan oleh orang yang menjamin melalui Panitera Pengadilan Negeri.

d. Apabila penjamin tidak dapat membayar sejumlah uang yang ditentukan tersebut, juru sita menyita barang miliknya untuk dijual lelang dan hasilnya disetor ke Kas Negara melalui Panitera Pengadilan Negeri.

Jadi, untuk seseorang tersangka atau terdakwa dapat ditangguhkan penahanannya, perlu dipenuhi syarat-syarat dan ada jaminan yang harus diberikan sebagaimana telah dijelaskan di atas.

Namun, hal-hal yang disebutkan di atas adalah dalam ranah normatif dan dapat berbeda dengan praktiknya di lapangan. Pada praktik di lapangan, penangguhan penahanan tersangka atau terdakwa dengan jaminan uang sangat berbeda dari yang diatur di dalam KUHAP serta peraturan-peraturan pelaksanaannya. Misalnya saja, pihak Panitera Pengadilan Negeri tidak pernah memberikan tanda terima atas penyerahan uang jaminan yang diberikan pihak tersangka atau kuasa hukumnya. Selain itu, uang jaminan atas penangguhan penahanan yang diberikan sebelumnya, seringkali tidak pernah dikembalikan kepada pihak yang memberikannya meski terdakwa kemudian dinyatakan bersalah oleh pengadilan.

Dalam hal ini juga sama dengan kejadian di atas, bahwa pelaksanaan proses penangguhan penahanan belum sepenuhnya berjalan sesuai dengan undang-undang yang berlaku, meskipun sebagian besar telah sesuai peraturan yang ada, karena ada perbedaan dalam hal jaminan penangguhan penahanan, yang mana uang jaminan yang seharusnya dibayar dan disimpan di Pengadilan Negeri melalui kepaniteraan Pengadilan Negeri, namun dari pihak penyidik justru mengambil uang penjaminan 
tersangka atau terdakwa untuk biaya penyelesaian administrasi selama penyidikan dan proses penyelesaian hukum.

Jadi, uang jaminan dari pihak penjamin tersangka bukanlah merupakan uang jaminan, melainkan untuk membayar administrasi atas perbuatan tersangka. Hal ini tentu berbeda dengan aturan yang ada karena uang jaminan pada dasarnya akan dikembalikan jika tersangka yang tidak melanggar peraturan dan syarat-syarat tertentu, artinya ketika masa penangguhan penahanan hingga sampai proses hukum selesai, sesuai peraturan yang berlaku, maka pihak penjamin atau pihak tersangka berhak untuk menerima kembali uang jaminan tersebut dan pihak pengadilan atau penyidik harus mengembalikan kepadanya.

\section{E. Kesimpulan}

Berdasarkan uraian dari hasil pembahasan di atas, maka penulis menyimpulkan sebagai berikut :

1. Pengertian penangguhan penahanan adalah mengeluarkan tersangka atau terdakwa dari penahanan sebelum batas waktu penahanan berakhir dan alasan yang sah untuk mengajukan penangguhan penahanan adalah selain menjamin berupa uang atau orang, tersangka atau terdakwa wajib lapor, tidak keluar rumah dan tidak keluar kota.

2. Pelaksanaan penangguhan penahanan terhadap tersangka atau terdakwa dalam perkara pidana narkoba adalah belum sepenuhnya berjalan sesuai dengan undangundang yang berlaku karena uang jaminan yang seharusnya dibayar dan disimpan di Pengadilan Negeri melalui Kepaniteraan Pengadilan Negeri, namun dari pihak penyidik justru mengambil uang penjaminan tersangka atau terdakwa untuk biaya penyelesaian administrasi selama penyidikan dan proses penyelesaian hukum.

\section{F. Saran}

Berdasarkan dari kesimpulan di atas, maka penulis memberikan saran yang berguna, baik bagi penulis khususnya maupun bagi pembaca penelitian mandiri ini pada umumnya. Adapun saran yang dapat penulis sampaikan sebagai berikut :

1. Kepada pihak penyidik (polisi) seharusnya melaksanakan ketentuan aturan yang telah diberlakukan oleh pemerintah demi mewujudkan keadilan. 
2. Kepada pihak tersangka apabila ingin meminta penangguhan penahanan harus menanyakan terlebih dahulu prosedur penangguhan penahanan kepada penyidik (polisi), sebab jaminan uang tersebut bukan untuk biaya penyelesaian administrasi selama penyidikan dan proses penyelesaian hukum.

\section{F. Rekomendasi}

1. Agar norma ketentuan pidana pelanggaran isi siaran televisi, dapat memenuhi asas kepastian hukum, keadilan dan kemanfaatan hukum, sedemikian sehingga mampu menangkal ditayangkannya siaran-siaran yang dapat memicu lahirnya kriminalitas anak akibat tayangan televisi, maka harus dilakukan:

a. Revisi Pasal 57 Undang-Undang Penyiaran dengan memperjelas dan mempertegas maksud, batasan atau kriteria, atau dalam keadaan yang bagaimana sebuah tayangan disebut melanggar isi siaran yang dapat memicu lahirnya kriminalitas anak;

b. Merumuskan pemidanaan yang tidak sekedar hanya dapat dijatuhkan kepada pelaku pada level pelaksana, melainkan harus mampu menjerat jajaran pimpinan perusahaan televisi. Kesalahan pimpinan perusahaan dimaksud, dirumuskan sebagai norma dalam pertanggungjawaban pidana korporasi.

c. Merumuskan ketentuan tentang pidana minimum yang harus dijatuhkan kepada pelaku pidana penyiaran, umpamanya pidana paling singkat yang dapat dijatuhkan kepada pelaku perbuatan pidana perbuatan pidana menayangkan isi siaran yang dapat memicu kriminalitas anak, adalah 1 (satu) tahun.

2. Agar konsepsi kebijakan hukum pidana yang diajukan benra-benar dapat diwujudkan demi menangkal dampak buruk tayangan televisi terhadap kriminalitas anak, maka Undang-Undang Penyiaran harus segera direvisi

\section{G. Daftar Pustaka}

Bambang Poernomo, Orientasi Hukum Acara Pidana Indonesia, Amarta Buku, Yogyakarta, 2000.

Hilman Hadikusuma, Bahasa Hukum Indonesia, PT. Alumni, Bandung, 2010.

Pudi Rahardi, Hukum Kepolisian Kemandirian, Profesionalisme dan Reformasi Polri, Cetakan Pertama, Laksbang Grafika, Surabaya, 2014. 
R. Soesilo, Tugas Kewajiban dan Kewenangan Penyidik, Jaksa, Hakim (Dalam Penyelesaian Perkara Pidana Menurut KUHAP), Sinar Grafika, Bandung, 2003.

Yahya Harahap, Pembahasan Permasalahan KUHP dan Penerapan KUHAP, Sinar Grafika, Jakarta, 2002. 